\title{
Valores e Objetivos da Educação Brasileira: a Questão da Relação entre Filosofia da Educação e Política Educacional, a partir de 1930
}

Sônia Martins de Almeida Nogueira

Universidade Federal do Rio de Janeiro (UFRJ)

Este estudo pretende explorar duas questões que se levantam a partir da análise da relação escola-sociedade-cultura. Essas questões se referem ao papel da filosofia da educação e à intervenção do Estado na educação, via legislação do ensino. Assim, é desenvolvida uma breve reflexão sobre a filosofia da educação, considerada uma íntima relação entre educação e axiologia, $e$ são analisadas as exposições de motivos e os relatórios de grupos de trabalho, elaborados para a apresentação e justificativa dos documentos das reformas de ensino de 1931,1942, 1964, 1968 e 1971, buscando-se elementos que favoreçam a identificação de valores subjacentes, possíveis reveladores de uma efetiva intenção política de ruptura do sistema de ensino com os objetivos $e$ valores da filosofia educacional.

\section{Introdução}

No processo histórico de institucionalização da ação educativa, a escola, à luz de ideologias explicitas inspiradas nas filosofias educacionais a que se tem filiado, define-se muito mais como instrumento de preservação de modos tradicionais de vida e de promoção de conformidade social. Percebe-se que sua própria inércia e os critérios valorativos que têm informado a política educacional ao longo desse processo histórico, no Brasil, não permitem que a escola se situe no processo evolutivo da criação e recriação da cultura, mas, apenas, que se identifique como instituição que responde à necessidade de transmitir e consolidar situações emergentes da interação social. Uma vez que essas situações, na história da sociedade brasileira, revelam a preservação do conservadorismo cultural, a escola tem servido à consolidação da hegemonia da classe dominante (Nogueira, 1987).

A análise oo papel da escola em face do problema da inovação educacional - transição do tradicional à mudança social, portanto entendendo-se que na escola transitam forças antagônicas geradoras de um processo de inovação - permite levantar dois pontos a partir dos quais se pretende desenvolver este trabalho. O primeiro refere-se ao papel da filosofia cia educação, o que exige

R. bras. Est. pedag. Brasília, 72(171):145-174, maio/ago. 1991 
que se abordem os conceitos de cultura e de ideologia para o estudo da relação essencial entre valores e educação. O segundo preocupa-se com a intervenção do Estado na educação, via legislação do ensino ${ }^{1}$; essa intervenção visa à implantação de uma política educacional, estabelecida a fim de que o sistema educacional cumpra as funções que lhe são atribuídas como instituição e, como tal, instrumento desse mesmo Estado.

Assim, tem-se como objetivo desenvolver uma reflexão sobre o papel da filosofia da educação, considerada uma íntima relação entre educação e axiologia, e analisar as exposições oe motivos e os relatórios de grupos de trabalho que introduzem a legislação do ensino, a partir de 1930, em busca de elementos que favoreçam a identificação de valores subjacentes nesses documentos.

\section{Cultura, Ideologia e Filosofia da Educação}

Cultura pode ser entendida como um ato de construção do homem diante da realidade objeitva do mundo que o desafia. O homem existe no tempo e suas relações com o mundo permitem que ele não se reduza à dimensão de sua natureza, mas que sua visão crítica e seu poder criador o situem na dimensão cultural. Segundo Freire (1974, p.43), a partir de suas relações com a realidade, o homem, pelos atos de criação, recriação e decisão, dinamiza o mundo e faz cultura.

Sendo um contexto no qual os acontecimentos sociais, os comportamentos, as instituições ou os processos podem ser descritos de forma inteligível (Geertz, 19- -, p.43), a cultura é obra dos homens. Ela é um processo de criação em que o homem, entretanto, enquanto ser social, é sujeito e agente.

O conceito de cultura abriga componentes que podem ser abordados em três grandes categorias: as instituições, as idéias e os produtos ou artefatos materiais que são produzidos e usados no curso da existência do homem. Neste estudo, as categorias das idéias e das instituições interessam especificamente.

As idéias, geradas, pois, na comunidade humana, abrangem as crenças, o conhecimento e os valores, que constituem fenômenos sociais complexos. São os valores, como componentes da cultura, que desejamos destacar, em face da premissa de uma relação essencial entre valores e educação.

Os valores não são regras específicas de ação numa determinada comunidade humana, mas representam padrões e ideais pelos quais seus membros definem seus objetivos, escolhem o rumo de suas ações e fazem juízos de valor ( Nogueira, 1987). Tomando o pensamento de Hessen, segundo o qual é da essência do ser humano valorar, e admitindo que a atividade axiológica ex-

${ }^{1} \mathrm{O}$ ponto de partida é a relação entre Estado e Educação, no Estado Intervencionista. A legislação é uma das formas de intervenção. O estudo da questão pode ser aprofundado através da leitura dos trabalhos de Horta e Comparato (ver referência bibliográfica). 
pressa a relação do homem com o mundo, é possivel dizer que a cultura é a realização de valores - "este é o seu sentido e a sua essência" (Hessen, 1980, p.247). Deste modo, o processo histórico da cultura é a expressão da realização de valores.

Esse processo histórico incorpora a dimensão política que os fenômenos sociais assumem na sociedade moderna, e tal dimensão se relaciona com a 'visão de mundo" oriunda da relação dos indivíduos com a realidade. Portanto, a análise do conceito de ideologia poderá oferecer uma contribuição para o estudo dos valores que estão imbricados nas diretrizes da política educacional.

Ideologia é uma visão peculiar do "mundo", visão que se organiza a partir de um processo de valoração que emerge da relação de cada indivíduo com o real. Nessa relação, os indivíduos procuram explicar e compreender sua própria vida, suas relações com os outros, com a natureza e com o sobrenatural; assim, elaboram idéias que expressam as condições reais, mas que podem explicar ou traduzir um ocultamento da realidade. Tais idéias têm razões (causas conscientes) para surgirem e se conservarem; seu conjunto constitui uma "visão do mundo" e expressa a consiqüência de reflexão. A partir dessa "visão de mundo", a ação do indivíduo se toma orientada, mais coerente e compreensível.

O conceito de ideologia suscita discussão, uma vez que sua problemática se coloca como essencialmente política; no entanto, nos limites deste estudo, essa discussão se restringe à relação da ideologia com a educação. Sendo ideologia o conjunto de valores hierarquizados, que sustenta os pressupostos do indivíduo quando procura compreender e explicar a realidade, ela pode ter credenciais de universalidade, considerado um determinado grupo social; entretanto, é possível que tal universalização represente a generalização das idéias de um grupo dominante, veiculadas através das instituições sociais - ideologia como imagem "perversa" da realidade social, a serviço da dominação.

Essa hegemonia no plano das idéias alcançada pela classe dominante (econômica, social e politicamente) levanta para a educação duas questões, que se comportam como complementares ou antagônicas: 1) a educação é o veículo privilegiado através do quai a ideologia da classe dominante é apreendida e interiorizada; 2) a educação é o instrumento, também privilegiado, para identificar, desmascarar a ideologia e transformar a sociedade (Matteo, 1983, p.39).

Tais questões, por conterem projetos educativos originados nas contribuições filosóficas que informam o caráter político da educação, remetem a um necessário exame do papel da filosofia da educação. Como ponto de partida, é preciso entender que filosofia é fundamentalmente uma atitude que o homem toma perante a realidade. Indagar é uma atitude filosófica autêntica

Saviani (1985, p23) explicita que a filosofia é o afrontamento, pelo homem, dos problemas que a realidade apresenta, não se caracterizando, pois, por um conteúdo específico; ao desafio da validade representado pelo proble- 
ma - uma questão cuja resposta se desconhece e se necessita conhecer -, o homem responde com a reflexão².

Os problemas apresentam-se ao educador e ele deve responder a eles com a reflexão. Os problemas encontram-se na própria ação de educar e exigem, pelo objeto dessa ação - a pessoa humana -, uma reflexão sobre a situação existencial concreta desse objeto. Cabe, portanto, à filosofia da educação oferecer um método de reflexão ao educador para que examine as questões, cujas respostas desconhece, com rigor, profundidade e globalidade, sem hierarquizar tais critérios e mantendo uma relação dialética entre eles na unidade da reflexão filosófica; entretanto, por se situar sempre numa posição de reflexão crítica, ela também propõe soluções (críticas e reflexivas) em relação aos problemas educacionais.

Retomando as categorias da cultura, é preciso fazer referência à escola como instituição. O processo de institucionalização da educação acompanhou o desenvolvimento da sociedade na medida em que se tomaram mais complexas as relações sociais; a escola apresenta-se como o locus onde a ação educativa se processa visando aos objetivos da política educacional definida pelos detentores da hegemonia do Estado. Não são levadas em conta, neste momento, as teorias de educação que orientam a referida ação, buscando-se apenas identificar a escola como instituição e, como tal, objeto da intervenção do Estado.

\section{Educação sob o ponto de vista axiológico}

\subsection{Critérios valorativos diversos que têm informado a política educacional brasileira}

No que concerne ao que se considera valioso, caracterizam-se duas atitudes, que fundamentam, em linhas diversas, o papel da escola e consubstanciam uma oposição entre suas expressões do ideal pedagógico. A primeira delas considera a existência de valores absolutos, intemporais, alheios às contingências do meio humano concreto; a segunda considera a emergência dos valores a partir da dinâmica histórica e social - condições históricas concretas - e seu condicionamento em função do meio concreto. Segundo Suchodolski (1960, p.14-15), a base dessa oposição encontra-se na controvérsia filosófica da "filosofia da essência" e da "filosofia da existência", que se fundamentam nos enunciados filosóficos da "essência" e da "existência", partindo de concepções antropológicas, portanto diferenciadas. Os ideais pedagógicos originados em tais correntes filosóficas são, em conseqüência, opostos.

Refletir é entendido como examinar detidamente, prestar atenção, com características de radicalidade, criticidade (rigor) e visão de conjunto (globalidade). A reflexão filosófica é o filosofar e tem como conseqüência a ideologia. 
Pode-se identificar, portanto, uma atitude idealista, que se expressa no substancialismo, e uma atitude realista, que se expressa no subjetivismo. O substancialismo parte do princípio de que a forma já é dada em todas as suas possibilidades: o mundo existe em si e ele se dá sob a forma de coisas; quanto ao subjetivismo, o argumento é que toda realidade é subjetiva, ou seja, a essência do homem é construída por ele próprio, à medida que faz opções em face de suas possibilidades: o homem dá sentido às coisas (Granato, 1988).

O "idealismo" atribui à escola o papel de preservar, transmitir ou criar valores. A educação idealista é imposta de "fora", ou seja, todo movimento é externo ao ser e não afeta sua essência; ela promove a atualização de potencialidades do ser. Implica uma pedagogia da disciplina em que não são consultados os interesses e os motivos existenciais da natureza humana, procurando formar um tipo de homem conforme o conceito normativo que tem dele. $\mathrm{O}$ ideal pedagógico é, portanto, a educação para a ordem - a educação como instrumento de conservação dos valores tradicionais da classe dominante (Vilalobos, 1959, p.37).

O "realismo", por sua vez, atribui à escola um papel essencialmente revolucionário: a escola como instrumento para a desagregação da cultura tradicional e para a provocação de mudança cultural. Vilalobos (1959, p.35) afirma que o "realismo" opõe-se ao "idealismo" na medida em que, "consciente da dinâmica histórica e social e do condicionamento dos valores em função do meio concreto, nega implicitamente à educação fins únicos e eternos". Ele identifica para a escola, em conseqüência, o papel de se adaptar às contingências do dever histórico e de favorecer a mudança. Assim, entende-se a proposta de educação para uma nova ordem social.

O enunciado filosófico da existência acolhe o processo educativo como o "florescimento espontâneo do ser humano e a realização de todas as suas potencialidades físicas e espirituais" (Vilalobos, 1959, p.37). Esse processo fundamenta-se, portanto, nos princípios da liberdade e do interesse, acolhendo que a realidade é construída pelo homem mediante um movimento interno (Granato, 1988). Qualquer proposta de educação, pois, deverá ter como ponto de partida uma análise histórico-existencial da condição humana (Matteo, 1983, p.41)

O ideal pedagógico da educação "realista" é a educação para a liberdade; a crescente consciência da dignidade do ser humano, como um fim em si mesmo, fundamenta o ideal democrático da igualdade entre os homens; e a realização desse ideal encontra na liberdade sua condição concreta. "É fundamental, contudo, partirmos de que o homem, ser de relações e não só de contatos, não apenas está no mundo, mas com o mundo. Estar com o mundo resulta de sua abertura à realidade, que o faz ser o ente de relações que é" (Freire, 1974, p.39). Estar com o mundo permite ao homem assumir sua existência e a existência assumida é a liberdade (Trigueiro, 1987, p.106).

O essencialismo e o existencialismo, consideradas as concepções antropológicas que os inspiram e os valores delas emergentes, apresentam-se ao 
longo da história da educação brasileira. Segundo a classificação de Saviani (1987, p.24), podem ser identificados no "humanismo" tradicional e no "humanismo" moderno ${ }^{3}$. O estudo das tendências da educação brasileira, com base na política educacional e na legislação de ensino, permite afirmar a presença do "humanismo" tradicional e moderno como concepções fundamentais das quais se radicam os valores declarados e os ideais pedagógicos manifestos, mas se faz necessário buscar uma argumentação consistente para essa afirmação.

Na periodização elaborada por Saviani $(1987$, p.33) para a análise do desenvolvimento da educação brasileira, o "humanismo" tradicional predomina até 1930; a partir dessa década, a tendência humanista moderna identifica-se com uma nova vertente do pensamento pedagógico, trazida com o advento da Escola Nova (1987, p.33). A escola tradicional brasileira, que se configurou desde a educação jesuítica e se manteve predominante no Império ena $1^{\S}$ República, apresenta-se como humanística e retórica por excelência, fundamentada nos mesmos valores e nos mesmos ideais de cultura ${ }^{4}$. A partir de 1930, a política educacional brasileira consubstanciou a abertura de caminhos para a renovação do sistema de ensino, como resultado do processo de democratização em desenvolvimento do País.

Foi, portanto, esse o momento em que, com base nas condições objetivas de mudança cultural em desenvolvimento desde as últimas década do Século XIX, o ideal de uma nova pedagogia começou a se impor e a educação brasileira partiu para a conquista de uma escola pública e eficiente como educação para uma nova ordem social ${ }^{5}$.

Saviani (1987) identifica quatro concepções fundamentais de Filosofia da Educação: "humanismo" tradicional; "humanismo" moderno; analítica e dialética. Argumenta que nessa classificação são destacados apenas os traços distintivos das diferentes concepções de Filosofia da Educação e busca explicar como elas se articulam com a organização educacional historicamente considerada.

Não se pretendeu nesta argumentação um estudo das grandes correntes filosóficas que têm inspirado a pedagogia, mas apenas identificar os critérios valorativos que têm informado a politica educacional brasileira como ato introdutório ao que se deverá analisar no item 4 deste trabalho. Recomenda-se ver, a respeito, B. Suchodolski, A Pedagogia e as Grandes Correntes Filosóficas.

O processo de urbanização e secularização da cultura, a incorporação de amplas camadas populares à vida ativa da nação, o florescimento de uma pequena burguesia industrial, como conseqüência da instituição do trabalho livre, da imigração em larga escala, da mudança do regime politico, do crescimento dos centros urbanos e da industrialização, que começava a acelerar seu ritmo, repercutiram na organização social e, em decorrência, na politica educacional. Ver J. E. Vilalobos, O Problema dos Valores na Formação e no Funcionamento do Sistema Educacional Brasileiro.

R. bras. Est. pedag. Brasília, 72(171):145-174, maio/ago. 1991 
A década de 30 trouxe para o Brasil uma aparente mudança da relação entre o poder público e o ensino. Em 1934, a Constituição atribuiu à União competência para fixar diretrizes e bases da educação nacional, o que pela primeira vez expressou uma preocupação com um plano nacional de educação. A defesa da escola pública, do ideal democrático de educação para todos e da conseqüente responsabilidade do Estado com a extensão universal do processo de escolarização, é feita sob inspiração do "humanismo" moderno, do ideal pedagógico da educação para a liberdade.

Os anos 30 representaram a culminância da transição de uma proposta pedagógica voltada para a formação de uma cultura livre e desinteressada, no sentido de ausência de responsabilidade social, para uma nova proposta de educação consciente dessa responsabilidade, adaptada às exigências do saber científico. Não se configurou, entretanto, em termos reais, a transição de um sistema de ensino limitador de seus benefícios às elites sociais para um sistema de ensino democrático, universalizado.

As perspectivas da educação que se delineiam ao longo do período que se inicia em 1930 e alcança nossos dias, fundamentadas na pedagogia da existência, podem ser apresentadas em três grupos. O primeiro abriga as perspectivas que supervalorizam o papel da educação na dinâmica da mudança; o segundo, as que subestimam esse papel; o terceiro, as que se situam na relação dialética entre educação e sociedade.

A educação como fator de mudança social, o primeiro grupo, tem por base as teses democrático-liberais. "Mesmo após o declínio da ideologia liberal, subsiste uma visão liberal de educação, que pode ser conservadora ou até mesmo progressista e modernizante (Horta, 1987, p.206); assim, o Estado Intervencionista, que se instalou como lorma de Estado a partir da Revolução de 30 , acolheu os princípios fundamentais do liberalismo que enfatizam a idéia da competência, ou seja, a tese do mérito individual e da educação como instrumento privilegiado da mobilidade social. Essa perspectiva abriga o progressivismo e as propostas radicadas na teoria do capital humano.

No segundo grupo, a educação apresenta-se como reprodutora das relações sociais a serviço do sistema, com fundamento nas teses reproducionistas; nessa perspectiva, identificam-se as teorias crítico-reprodutivistas, segundo nomenclatura de Saviani, que explicita haver nelas "uma cabal percepção da dependência da educação em relação à sociedade" (1985, p.19). Constata esse autor que, ao analisarem a função da escola, tais teorias revelam um processo de reprodução da sociedade de classes e do modo de produção capitalista; são criticas, portanto, porque se empenham em compreender a educação remetendo-a à estrutura sócio-econômica que a condiciona, e são reproducio- 
nistas por entenderem a reprodução como função básica da educação (Saviani, 1985, p.9).

O terceiro grupo agrega as perspectivas da relação dialética entre educação e sociedade ${ }^{6}$. Tais perspectivas estão fundamentadas nas teses da teoria da reconstrução social e abrigam as diretrizes de ordem fenomenológica, existencial e marxista; portanto, as contribuições filosóficas são oriundas do existencialismo e do materialismo dialético; o primeiro destacando a responsabilidade individual - o homem é um sujeito, uma existência que é chamada a se dar uma essência, através de suas decisões livres - e o segundo proporcionando uma releitura da realidade social, desvelando a alienação e propondo a superação e a transformação da realidade (Matteo, 1983, p.42).

Essas perspectivas representam o pensamento pedagógico brasileiro ao longo do processo histórico, que tem como marco inicial a década de 30; entretanto não se apresentam na mesma linha de evolução da politica educacional quando se consideram os planos de governo e a legislação de ensino, nem se expressam nos textos legais, à exceção das que se abrigam no primeiro grupo. Por representarem concepções de educação, sua caracterização tornou-se necessária como subsídio à reflexão sobre os valores que inspiram a política educacional.

\section{Política educacional e valores na educação}

Retoma-se neste ponto a ênfase sobre o papel da Filosofia da Educação, para favorecer o encaminhamento da análise da intervenção do Estado na educação, via legislação de ensino, intervenção que é feita visando à implantação de uma política educacional que conduza a educação ao encontro dos interesses e metas do Estado.

Cabe à Filosofia da Educação analisar os valores declarados e os valores subjacentes às políticas educacionais, através do estudo dos planos nacionais de educação, dos documentos doutrinários e normativos e dos discursos e outros pronunciamentos das autoridades governamentais e educacionais. Essa análise tem como foco a intersecção entre a objetivação ética representada pela política educacional e a subjetivação ou interiorização dos valores. É da competência da Filosofia da Educação problematizar o espaço da autonomia, liberdade e criatividade dos educandos, indagando até que ponto a consciência humana tem autonomia para introjetar valores e aprendê-los dialeticamente (Maia, 1987).

A legislação de ensino expressa as diretrizes políticas norteadoras do processo educativo a ser desenvolvido na escola. É ela que rege a operaciona-

\footnotetext{
As teses que fundamentam estas perspectivas são consideradas neste estudo: $1^{9}$ ) sob o ponto de vista axiológico, e neste caso intimamente relacionadas ao politico-ideológico, e $2^{\circ}$ ) sob o ponto de vista antropológico, este concernente à concepção de homem.
} 
lização dessas diretrizes. Por outro lado, a interpretação de seus dispositivos dá origem a diferentes ações políticas nos níveis federal, estadual e municipal, todas, entretanto, em consonância com os princípios geradores desses dispositivos. Entende-se, pois, que o estudo rigoroso da legislação ofereça elementos para a identificação dos valores inspiradores da política educacional ${ }^{7}$.

Acredita-se, no entanto, que as exposições de motivos e os relatórios de grupos de trabalho, como documentos que precedem e introduzem a legislação, consubstanciam os valores declarados e subjacentes de modo mais claro; deste modo, nos limites dos objetivos deste estudo, far-se-á a leitura desses documentos pretendendo conhecer esses valores.

\section{Exposição de Motivos da Reforma Francisco Campos (1931)}

Os estudos de filosofia, de sociologia e de psicologia já ofereciam, à época, elementos para que uma proposta educacional se fundamentasse no princípio da educação identificada com a vida, ou seja, relacionada à atividade social e profissional da pessoa humana e à totalidade de sua vida individual. Por outro lado, as forças sociais afluentes provocavam rompimento na unidade do pensamento educacional brasileiro, que ainda se encontrava "dominado pela tradição e marcado pela herança jesuítica, literária e humanística" (Costa, 1984,p.134).

A Reforma Francisco Campos abrange os cursos secundário, superior e de ensino comercial. A do ensino secundário é teoricamente a que expressa uma reforma ampla, porque buscou a verdadeira finalidade desse nível de estudos: " atribuiu-lhe feição formativa, ao mesmo tempo em que tentou definirIhe terminalidade própria" (Costa, 1984, p.136).

Essa finalidade é expressa no texto da Exposição de Motivos: "o seu fim, pelo contrário, deve ser a formação do homem para todos os grandes setores da atividade nacional, construindo no seu espírito todo um sistema de hábitos, atitudes e comportamentos que o habilitem a viver por si mesmo e a tomar em qualquer situação as decisões mais convenientes e mais seguras" (p.47-48).

Alguns elementos precisam ser destacados para que se possa argumentar em relação aos critérios valorativos que inspiram, segundo se supõe, a Reforma de 31. São eles: 1) função do ensino secundário: "função eminentemente educativa, que consiste, precisamente, no desenvolvimento das faculdades de apreciação, de juízo e de critério, essenciais a todos os ramos da atividade humana e, particularmente, no treino da inteligência em colocar os problemas nos seus termos exatos e procurar as suas soluções mais adequadas" (p.45); 2) teoria da educação: "A verdadeira educação concentra seu interesse antes

É necessário reafirmar aqui que a legislação de ensino é uma das formas de intervenção do Estado e que se relaciona com o planejamento educacional e com a educação pública de diferentes maneiras, em face de condicionamentos históricos. Ver Baia Horta, op. cit., p.195. 
sobre os processos de aquisição do que sobre o objeto que eles têm em vista, e a sua preferência tende não para a transmissão de soluções já feitas, acabadas e formuladas, mas para as direções do espírito, procurando criar, com os elementos constitutivos do problema ou da situação de fato, a oportunidade e o interesse pelo inquérito, a investigação e o trabalho pessoal, em vista da solução própria e adequada e, se possível, individual e nova" (p.48); 3) relação escola/democracia: "Só aprendemos o que praticamos. Se, portanto, é dever da escola formar cidadãos ou educar para a democracia, ela só o fará não por meio de pregações, sermões, conferências ou lições, mas organizando-se democraticamente e praticando, de modo efetivo e prático, a democracia" (p.51).

Esses elementos permitem configurar um ciclo revolucionário no setor eaucacional, que já vinha questionando a escola brasileira, incluindo-se na efervescência cultural e intelectual que se antecipou às próprias mudanças políticas desencadeadas em 1930. A adesão de educadores vanguardistas do pensamento pedagógico ao movimento da Revolução, entretanto, não gerou programas especificamente educacionais na plataforma política da Aliança Liberal, mas concretizou a criação do Ministério da Educação e Saúde Pública (1930), expressão de antigas reivindicações, depositário dos anseios por uma educação moderna e técnica e agente da aceleração do processo de transformações e inovações educacionais, segundo acreditavam os educadores naquele momento (Costa, 1984, p.135).

Percebe-se no texto da Exposição de Motivos a rejeição às doutrinas da realidade absoluta e a enunciação dos conceitos básicos do progressivismo em relação à realidade, ao conhecimento e ao valor. A educação foi proposta no sentido recriador, reconstrutor da cultura, com base na experimentação, o que implicava uma escola com o currículo continuamente experimental, eliminando toda sorte de rotina acrítica, de limites absolutos, de soluções pré-fixadas.

Poder-se-ia destacar nessa exposição o impacto positivo da teoria progressivista na renovação da educação brasileira na Reforma Francisco Campos; entretanto é importante levar-se em conta a tensão dialética, inerente ao processo de mudança, entre o tradicional e o emergente, entre a realidade anterior e a realidade nova, expressão da nova ideologia, e as conseqüências dessa tensão na prática educativa.

O contexto cultural da Revolução de 30 , aparentemente propício à filosofia educacional experimentalista, permitiu a proposta de um ensino visando atender "às exigências e às pressões da vida contemporânea" (Exposição de Motivos, 1931, p.52). No entanto, poucas e tímidas foram as realizações nessa linha de filosofia educacional, pois, bem cedo, com a instalação do Estado Novo, as forças conservadoras "consolidaram na teoria e na prática da educação nacional o domínio total de um sólido conservadorismo cultural com todas as suas estamentações e dualismos aristocráticos..." (Abreu, 1976, p.52).

Faz-se indispensável uma referência a formação oe professores para o ensino secundário, alvo de breve consideração por parte de Francisco Campos ao evidenciar o fato de a educação dos jovens estar sendo entregue "ao acaso 
da improvisação e da virtuosidade" (p. 52). O Estatuto das Universidades Brasileiras, também datado de 1931 (reforma do ensino superior), criou a Faculdade de Educação, Ciências e Letras, com o objetivo, entre outros, de desenvolver e especializar conhecimentos necessários ao exercício do magistério, incluindo disciplinas fundamentais para a ciência da educação e disciplinas de cunho metodológico (Costa, 1984, p.139). Proposta oficialmente como a nova instituição para a formação do magistério, não se organizou, apesar da recomendação contida na Exposição de Motivos: "urge se instale o quanto antes, ainda que com sacrifícios" (p. 52). A necessidade formulada de preparação de professores para o ensino secundário constituiu-se em mais um dos esforços malogrados; configurou-se como uma exigência legal antes da efetiva inclusão dos estudos relativos à educação entre aqueles de nível universitário.

O texto da Exposição de Motivos da Reforma do Ensino Secundário de 1931 revela uma concepção educacional que se fundamenta na pedagogia da existência. Concretiza o enunciado de uma política educacional compartilhada por um setor muito significativo da sociedade civil, expressando uma aspiração que se antecipava à realidade. Inspiradora de uma legislação capaz de gerar uma crença no poder da educação em transformar a realidade social, incorporou-se ao modelo desenvolvimentista que se difundia; na prática, entretanto, a Reforma Francisco Campos assegurou o caráter dual do ensino, acentuando a divisão social do trabalho: ensino secundário propedêutico para as classes mais favorecidas; ensino comercial - cinco modalidades de cursos técnicos, com caráter de terminalidade - e curso superior de administração e finanças a serviço das classes populares. O ensino técnico ia ao encontro do modelo econômico que se inaugurava.

Em seu conteúdo, o documento ora analisado expressou o liberalismo na área educacional, que acompanhava a trajetória política dos princípios liberais, sendo esta voltada para a consolidação de uma sociedade democrática mediante a participação de todos.

\section{Exposição de Motivos da Reforma Capanema}

Em 1934, ao assumir o Ministério da Educação e Saúde Pública, Gustavo Capanema enfrentou as questões da política educacional e as diferentes correntes ideológicas que expressavam a efervescência do período de consolidação da Revolução de 30. A educação apresentava-se como um instrumento de formação de mentes, de promoção da mobilidade social e de participação política; como tal, representava o espaço político para o ideário de determinadas linhas de pensamento. Assim, o que se esperava à época era que o Ministério da Educação e Saúde Pública desempenhasse um papel central na formação profissionai, moral e política dos brasileiros e na constituição do próprio Estado Nacional (Schwartzman, Bomeny, Costa, 1984, p. 17).

Em 1937, entretanto, em conseqüência do golpe e instalação do Estado Novo, foi outorgada uma nova constituição, que se opunha aos ideais liberais

R. bras. Est. pedag. Brasília, 72(171):145-174, maio/ago. 1991 
da Carta de 34 e abrigava tendências centralizadoras e autoritárias. Os dispositivos concernentes à educação conduziram a uma politica educacional voltada para a nacionalização do ensino e para a formação da elite responsável pela defesa e manutenção dos interesses nacionais, caracterizando uma orientação de formação de mão-de-obra qualificada para atender ao processo de desenvolvimento do capitalismo.

A Reforma Capanema efetuou-se para direcionar a educação nos rumos da nova organização política que se instalara. A reforma abrangeu o ensino secundário e o técnico-industrial, reestruturando, posteriormente, o ensino comercial, e abriu caminho para as reformas do ensino primário e do ensino normal, realizadas efetivamente após a queda do governo Vargas.

\subsection{Exposição de Motivos da Lei Orgânica do Ensino Secundário}

Esse documento reafirma o caráter educativo do ensino secundário, que representara o ponto básico da Reforma de 31 como contraposição à conceituação de mero ensino de passagem para os cursos superiores. $O$ ensino secundário é entendido como tendo a função especifica de "formar nos adolescentes uma sólida cultura geral, marcada pelo cultivo a um tempo das humanidades antigas e das humanidades modernas, e bem assim de neles acentuar e elevar a consciência patriótica e a consciência humanística" (p.311).

Percebe-se uma ênfase na formação da consciência patriótica, que se justifica no objetivo de "preparação das individualidades condutoras", ou seja, a formação de líderes, portadores das concepções e atitudes espirituais a serem infundidas nas massas. O ensino patriótico não só deveria promover a compreensão da história, dos problemas, das necessidades, da missão e dos ideais da nação, mas, também, das ameaças internas e externas à soberania; era ainda seu objetivo o de conscientizar as novas gerações de sua responsabilidade diante dos valores, da manutenção da ordem e do destino da pátria (p.311).

Embora não se caracterize de maneira explícita, a leitura ao objetivo de formação de individualidades condutoras permite entender que se situava no ensino secundário a formação do cidadão, sendo este identificado no líder responsável por infundir nas massas os valores acolhidos pela sociedade política. A ele seriam propiciados estudos que conduzissem à compreensão do valor $\mathrm{e}$ do destino do homem - consciência humanística -, favorecendo uma concepção ideal de vida humana, e à apreensão da significação histórica da pátria, da importância de seu destino e da responsabilidade do indivíduo em relação à missão social e patriótica que lhe era atribuída.

Esse argumento se toma mais consciente ao serem considerados alguns pontos. São eles: 1) a gratuidade e a obrigatoriedade do ensino primário foram mantidas pela Constituição de 37 , mas a responsabilidade em relação ao ensino secundário não foi explicitada; 2) foi instituído, em caráter obrigatório, o en- 
sino de trabalhos manuais para todas as escolas primárias, secundárias e normais; 3) o ensino pró-vocacional e profissional configurou-se num programa de politica escolar como primeiro dever do Estado, mas destinado às classes menos favorecidas. Entende-se, pois, que a oportunidade de acesso ao ensino secundário limitava-se às classes mais favorecidas, às quais o ensino primário não se apresentava com caráter de terminalidade.

Entre os diferentes temas que foram alvo da Exposição de Motivos há ainda a destacar. 1) a clara referência feita a Dewey quanto à metodologia do ensino das ciências, em que Capanema recomenda um trabalho que atenda ao preceito deweyano de reconstrução da experiência; 2) o especial relevo dado ao ensino da educação moral e cívica, considerada como formadora do caráter e do patriotismo; 3) o comentário sobre a adoção da Orientação Educacional no ensino secundário, considerando que, junto com a administração escolar e o corpo docente, ela constitui um "organismo coordenado e ativo, capaz de assegurar a unidade e a harmonia da formação da personalidade do adolescente" (p.314); 4) estabelecimento de preceitos destinados ao desenvolvimento de assistência aos escolares necessitados, visando proporcionar, "o mais que for possível, a educação secundária aos adolescentes bem dotados" (p.314). Por último, assinala-se que o projeto é declarado como inspirado na "fecunda verdade pedagógica de que a educação deve ter vida a fim de que possa ser uma útil preparação para a vida"(p.314).

A leitura da Exposição de Motivos da Lei Orgânica do Ensino Secundário precisar, por orientada pelo contexto de uma ideologia nacionaldesenvolvimen-tista, defendida pelo Estado Intervencionista de acentuado caráter autoritário, de tendência nazi-fascista, em trânsito da aristocracia rural do café para uma nova força econômico-social vinculada às atividades urbanoindustriais. À educação cabia ser instrumento de formação de uma consciência nacional, de Veiculação das idéias do poder central, de arregimentação política, de preparação de contingentes para o sistema de produção e de formação de "individualidades condutoras".

\subsection{Exposição de Motivos da Lei Orgânica de Ensino Comercial}

Nesse documento, o ensino comercial define-se como o ramo de ensino secundário destinado à preparação para o exercício de funções específicas no comércio e de funções administrativas no serviço público e em empresas privadas. No primeiro ciclo, é suprimido o curso propedêutico de três anos, da legislação anterior, sob a justificativa do caráter profissionalizante do ensino comercial e da especificidade do ensino secundário em seu caráter propedêutico. No segundo ciclo, os cinco cursos técnicos são revistos em seu conteúdo e duração, visando à maior eficiência, e são criados dois novos cursos: de administração e de estatística, com o objetivo de atender ao desenvolvimento da organização administrativa e à necessidade de preparação de auxiliares de estatística para preenchimento de cargos, cujo número o aperfeiçoamento dos servi-

R. bras. Est. pedag. Brasília, 72(1711:145-174, maio/ago. 1991 
ços de estatística da administração pública, sobretudo, havia amplamente expandido.

A articulação do ensino comercial com o ensino primário, que o antecede, com o ensino ginasial e com o ensino normal de primeiro ciclo, representou um avanço em direção à escola única, sem contudo assim ser considerado por Capanema. A integração vertical com o primário, dispensando o curso de admissão, e com quaisquer cursos do segundo ciclo, conduzindo posteriormente a curso de ensino superior relacionado com os estudos concluídos, atenua, enquanto proposta, os efeitos da dicotomia educação técnica/educação humanística, sobretudo porque Capanema recomendou a inclusão no currículo do ensino comercial de disciplinas de cultura geral e de práticas educativas, visando complementar a formação intelectual, física e moral dos adolescentes.

\subsection{Exposição de Motivos do Projeto do Decreto-Lei Relativo à Aplicação da Lei Orgânica do Ensino Industrial}

O que se destaca nesse documento é a proposta de um regime de emergência nos estabelecimentos oficiais de ensino industrial, com o objetivo de, a curto prazo (três anos), "mobilizar os contingentes necessários de trabalhadores habilitados", principalmente para indústrias e empresas ligadas à defesa nacional. Esse regime visava, também, propiciar o desenvolvimento das qualidades técnicas e pedagógicas dos professores de ensino industrial.

Tal proposta revela uma preocupação com a segurança nacional, fruto do momento histórico da 2- Guerra Mundial, expressa na formação de pessoal qualificado para assegurar a eficiência da política de industrialização, instrumento de superação da dependência econômica e de consolidação da nossa soberania.

\subsection{Uma leitura integrada dos três documentos}

Em seu conjunto, os documentos não visualizam o sistema educacional como um todo. Seus aspectos predominantes são a valorização do ensino técnico e o reforço ao dualismo educação humanística/educação para o trabalho.

Percebe-se a ideologia liberal imbricada na proposta de um currículo com base pragmática, utilitária, mas os postulados fundamentais dos educadores da Escola Nova - educação popular, universalidade e gratuidade da educação, democratização do ensino, educação integral para ambos os sexos - não são identificados nos textos lidos. A educação popular, por exemplo, entendida . pelos progressivistas como educação para todos em escola única ${ }^{8}$, apresenta-

O conceito de escola única para esses educadores é o de escola comum para todos, sem subdivisões em ramos de ensino, oferecendo a mesma educação geral e visando ao objetivo de assegurar ao indivíduo o direito de ser educado até onde suas aptidões naturais o permitam independentemente de suas condições econômicas e sociais. É, portanto, uma escola organizada para a coletividade em geral. Ver Manifesto dos Pioneiros da Educação Nova Revista Brasileira de Estudos Pedagógicos, Brasília, v.65, n.150, p.407-425, maio/ ago. 1984. 
se no dualismo acima referido; a responsabilidade total do Estado em relação à educação, pleiteada pelos escolanovistas e que poderia concretizar o ideal de democratização, não se configura $O$ estudo da história da educação nesse periodo informa que o Estado se apoiava na ideologia da Escola Nova, enquanto dava respaldo à política populista e nacional-desenvolvimentista, mas, por outro lado, atendia ao setor privado, religioso e laico, enquanto mantenedores do dualismo e dos elementos de controle do meio social.

A política educacional manifesta nos três documentos, que atende à orientação firmada na Constituição, de uma educação para o trabalho, abriga tanto a ideologia educacional do Estado como a ideologia liberal. Os fundamentos filosóficos parecem assentar-se no pragmatismo e no humanismo tradicional, pois, enquanto norteiam uma educação utilitarista, expressam-se no pensamento educacional voltado para a preservação dos valores herdados, o ajustamento do homem à sociedade, o treinamento intelectual e a construção do caráter mediante disciplina formal e a incorporação do movimento científico à educação: é uma educação para a ordem, visando à unidade nacional. Convivem, portanto, nos textos, os princípios da educação idealista e os da educação identificada com a vida - a realista, a pedagogia da essência e a pedagogia da existência.

Embora represente um retrocesso em relação à Reforma de 31 e seja, por isso, considerada reacionária, a Reforma Capanema contém, na contradição de acolher nas exposições de motivos ora em foco duas correntes pedagógicas que se opõem, um dilema presente à época na filosofia da educação: o conflito entre a pedagogia da essência e pedagogia da existência. Segundo Suchodolski (1960, p.111), "a contradição entre as tendências da educação que buscam satisfazer as necessidades do indivíduo e as correntes pedagógicas fundamentadas no princípio da essência aparece com uma clareza particular na pedagogia moderna".

Concebida como a pedagogia que critica a concepção da educação baseada no princípio da essência, a pedagogia da existência traduz o ideal do indivíduo como uma projeção do presente no futuro, sua própria vida lendo em si as forças que criam o seu futuro. Deste modo, opõe-se fundamentalmente às concepções da pedagogia da essência (Suchodolski, 1960, p.111,112). Entretanto, como essa orientação não conduz, na realidade, a nenhuma concepção visando transformar as condições existentes e a nenhum ideal de vida individual ou social, é ainda Suchodolski quem argumenta, ela se distingue também por uma tendência para defender posições tradicionais da pedagogia da essência ${ }^{9}$ (1960, p.112). A convivência de duas correntes em oposição parece encontrar, no argumento exposto, uma justificativa.

\footnotetext{
${ }^{9}$ Suchodolksi refere-se à crítica que o existencialismo faz às duas orientações, considerando que nenhuma delas tem a concepção de um homem concreto, pertencendo a um lugar definido e a uma época definida na história - em uma delas o homem é reduzido a um simples "adquirente" e veículo de valores culturais e na outra ele se situa numa experiência contemplativa ou numa emoção mística. Assim, ele permanece num domínio limitado da vida humana, sem nenhuma relação seja com a atividade real, social e profissional do homem, seja com a totalidade de sua vida individual (Suchodolksi, op. cit., p.112)
} 
Nessa linha de reflexão, é preciso ainda considerar o momento histórico do Estado Novo. As décadas de 20 e 30 foram períodos de ampla discussão sobre os dois extremos do pensamento pedagógico - a educação identificada com a vida de tal modo que um ideal não era necessário; a presença norteadora de um ideal na educação de tal modo que a realidade não era necessária. $\mathrm{A}$ crítica acentuava as tendências naturalistas da pedagogia da existência e o caráter metafísico, ausente da realidade, da pedagogia da essência. A pedagogia, para atender às questões da natureza humana e suas necessidades, deveria ser a síntese da pedagogia da essência e da pedagogia da existência, mas essa síntese exigia condições que a sociedade, à época, não oferecia. As condições sociais e históricas existentes não eram propícias: o ideal não poderia sancionar o que expressava a atualidade, nem tomar uma forma estranha àquela realidade (Suchodolski, 1960, p.114-116).

As correntes nacionalistas de diversos países detiveram-se acentuadamente no problema, enfatizando, sobretudo, a oposição da realidade social à educação voltada para o indivíduo, tendo como princípio fundamental seu livre desenvolvimento. Era preciso considerar a participação do indivíduo na comunidade política nacional, que se sobrepunha aos valores universais perenes. Por tentarem vencer tanto a visão individualista quanto a universalista de educação, essas tendências terminaram por oferecer orientações para o fascismo e o nazismo. É possível que esta argumentação represente uma segunda justificativa, conseqüente à primeira, para a presença das duas doutrinas pedagógicas nas exposições de motivos da Reforma Capanema.

\section{Exposição de Motivos do Projeto de Lei de Diretrizes e Bases da Educação} Nacional - Reforma de 1961

O documento que propôs diretrizes e bases para a educação representou, no governo Dutra, o texto configurativo de uma preocupação revelada em suas plataforma de postulante à presidência $A$ educação caracterizava-se para 0 então candidato como um problema complexo, presente nas quesitões da familia, da saúde, da produção, da segurança social, apresentando-se como recurso indispensável para a realização de todos os planos e programas de governo (Mariani, 1948, p.1).

Foi, portanto, no governo de Eurico Gaspar Dutra, que tomou forma uma segunda iniciativa voltada para a concretização do princípio de ser traçada uma política educacional de âmbito nacional (Ribeiro, 1984, p.134,135) ${ }^{10}$. O então

A primeira iniciativa pode ser reconhecida nas medidas tomadas, durante o governo Vargas, no sentido de criação de uma série de ógaõs voltados para dar suporte às propostas pedagógicas contidas na legislação de ensino, abrangendo a reforma de 1942. Assim surgiram: o Instituto Nacional de Estudos Pedagógicos; o Serviço Nacional de Radiodifusão Educativa; o Instituto Nacional de Cinema Educativo; o Serviço de Patrimônio Histórico e Artístico Nacional; o Serviço Nacional de Aprendizagem Industrial e o Serviço Nacional de Aprendizagem Comercial. Outros órgãos foram criados durante o mandato de Vargas de 1951 a 1954. Otaíza Romanelli e Maria Luiza S. Ribeiro focalizam essas iniciativas em suas obras sobre história da educação brasileira (ver referência bibliográfica). 
ministro da Educação e Saúde, Clemente Mariani, encaminhou o projeto de lei, precedido por sua Exposição de Motivos, apresentando-o como "um conjunto de princípios, de bases, de limites e de faculdades flexíveis e criadoras" (p.16). Não foi, pois, a proposta de uma nova reforma de ensino, mas um projeto integrado, segundo Mariani, ao movimento de redemocratização do país, iniciado com o afastamento de Vargas da presidência em 1945.

Na perspectiva de concretizar uma política educacional em nível nacional, o projeto era entendido por Mariani como uma "constituição" de ensino, dando "origem aos sistemas estaduais e ao próprio sistema federal de educação, cujas leis deverão obedecer ao mesmo espírito, para que, no final sejam os próprios institutos de ensino organismos vivos e progressivos, capazes de revisão mediante alteração de seus próprios regimentos" (p.16). Esses sistemas se harmonizariam em função das diretrizes estabelecidas por uma política nacional de educação, mas, ao mesmo tempo, em vista de seu caráter, poderiam desenvolver ações visando à revisão de suas orientações, buscando atender à própria dinâmica Mariani considerou ser este o ponto revolucionário da proposta: uma educação que estaria em permanente processo de avaliação, deixando de ser o objeto de reformas sucessivas - "reformismo espasmódico" - e favorecendo a revisão das instituições de ensino.

O projeto foi encaminhado à Câmara Federal em outubro de 1948 e só transformou-se em lei em 1961. Esclarece-nos Maria Luisa S. Ribeiro (1984, p.135) que até 1952 o projeto se manteve em exame nas comissões parlamentares e que de 1952 a 1958 e de 1958 a 1961 transcorreram duas fases distintas de debates. A primeira tratou da interpretação do texto constitucional relativo à educação e a segunda abrigou os debates sobre um substitutivo que permitiu ser exacerbada a oposição entre os defensores do ensino público e os do ensino privado.

Os princípios teóricos orientadores contidos na exposição de motivos, redigida por Clemente Mariani, deveriam conduzir ao objetivo maior de democratização da educação, coerente com o propósito de restaurar a democracia como modelo político e social, inspirador das medidas governamentais em todos os setores. O primeiro desses princípios é o da descentralização; Mariani o considerou princípio fundamental, adotado pela Constituição em seus dispositivos sobre educação como decorrência da própria teoria do ensino e da organização política do país. Citando Alberto Torres, Mariani assinalou que "o problema da centralização e da descentralização não é mais de antagonismo, senão antes de harmonia, de penetração e de equilíbrio entre a função particular de cada órgão e as funções gerais de nacionalidade" (p.4).

Um outro princípio é o de integração, que se expressava na articulação vertical entre os diferentes graus de ensino, favorecendo o progressivo acesso às diferentes séries, eliminando as barreiras de ordem pedagógicas existentes, um dos muitos instrumentos de seletividade do sistema de ensino. Havia a pretensão de favorecer a educação das massas e eram renovados os mitos da mobilidade social via escolarização e do mérito: "fazer ascender os indivíduos verdadeiramente capazes, embora desprovidos de recursos, à esfera dos que, 
pela educação superior, constituem as classes dirigentes do país" (p.4).

A articulação horizontal entre as diferentes modalidades de ensino é a segunda face do princípio de integração. À luz dos sistemas francês, inglês e norte-americano, Mariani argumentou sobre a necessidade de democratização da educação secundária, devendo esta "elevar-se à altura de seu destino - o de produtiva e de expressão social" (p.5). A articulação horizontal entre os vários ramos e modalidades do ensino secundário se fazia, portanto, condição básica para remover as barreiras entre os estudos acadêmicos e os estudos técnicos. O principio de integração apresentava-se como corolário da democratização do sistema de ensino.

A unicidade do sistema de ensino constitui o terceiro princípio, atendida a autonomia estadual e municipal assegurada pela organização federativa. É a unidade nos objetivos que, como postulado constitucional, deveria ser, segundo Mariani, o substrato da legislação de ensino. Assim, o campo da norma seria objeto de uma legislação flexível e o processo educativo se renovaria na dinâmica das experiências e pelo conhecimento oriundo das pesquisas (p.5).

Clemente Mariani deixou claro em sua argumentação que, em consonância com a Constituição de 1946, que estabelecera a necessidade de uma política educacional livre da influência de sistemas filosóficos incompatíveis com os novos ideais de nacionalidade, a reestruturação democrática do sistema educacional haveria de ser assegurada pela lei de diretrizes e bases. Assim, esta lei teria uma premissa necessária: "a de ser nacional em seu objetivo. Isto é, a de visar, em última análise, à integridade da nação, às condições do seu progresso conjunto e à reafirmação constante daqueles valores que a criaram e a sustentam" (p.9).

Todos esses princípios se voltavam para o fortalecimento da unidade nacional, e a unidade do sistema de ensino seria garantida, entre outras medidas, "pela função unificadora, a ser exercida por três entidades centrais: o Ministério da Educação, o Conselho Nacional de Educação e a Conferência Nacional da Educação cuja influência, nem por ter força unicamente persuasiva, será menos valiosa e eficaz" (p.11).

Percebe-se uma indissimulável corrente nacionalista, cujo projeto na área educacional não se afasta, em suas teses básicas, das orientações da pedagogia da existência, mas acentua a intervenção da União e o objetivo de uma educação para a ordem. Os critérios valorativos da pedagogia da essência e as propotas pedagógicas inspiradas no pragmatismo e inseridas, também, nas exposições de motivos das duas reformas anteriores revelam um conflito dentro da própria sociedade, buscando esta submeter o indivíduo às condições sociais existentes.

Os educadores que discutiram os rumos da educação nacional nas décadas de 20,30 e 40, alguns deles responsáveis por experiências fundamentadas nos princípios da pedagogia da existência, não buscaram a síntese dessas duas concepções - a educação "idealista" e a educação "realista" -, tendo 
como base as condições históricas e sociais do momento considerado. Clemente Mariani, por sua vez, atribuiu à escola primária a função de promover a integração social e incutir na criança princípios e atitudes intelectuais e morais; ao ensino secundário cabia a formação do adolescente, visando atender tanto às necessidades do jovem quanto ao organismo social; o ensino superior, definido como de caráter seletivo, tinha por objeto "o desenvolvimento da alta cultura e da pesquisa científica, a especialização filosófica, literária, científica, técnica ou artística e a habilitação para o exercício das profissões técnico-científicas e liberais" (p.14). Essas funções não escondem a convivência de duas orientações que se contradizem.

A vigência da Reforma Capanema, num período em que, por um lado, o modelo nacional-desenvolvimentista acentuava a dependência do Estado aos interesses do capitalismo mundial e o processo de industrialização passava a exercer maior pressão na área educacional em função do mercado e, por outro lado, a prolongada discussão em tomo dos princípios fundamentais da Lei de Diretrizes e Bases adiava a aprovação de seu texto final e conseqüente homologação, parece ter sido um dos fatores que permitiram a Jayme Abreu afirmar, em 1960, que a escola brasileira se encontrava "vinculada prevalecentemente ao que é definido como perenialismo e, subsidiariamente, máxime quando a nossa república recém-instaurada tinha mais republicanos do que hoje, ao essencialismo secular, na escola pública" (1976, p.51). E ainda: "É assim, ao nosso ver, particularmente grave em relação a uma sociedade progressivamente em mudança como a nossa, por industrialização, urbanização, ciência, secularização da cultura, e a um país para quem o desenvolvimento e o crescimento, lato sensu considerados, são imperativos de sobrevivência, ver a sua ação escolar atida completamente ao monopólio de filosofias educacionais passivas, sumamente conservadoras, ou mais do que isto, regressivistas em seu anacronismo cultural" (p.53-54).

\section{Relatório de Grupos de Trabalho: as Reformas de 1968 e de 1971}

A década de 60 na educação brasileira representa um período muito marcante porque abrigou, em seu início, movimentos que expressaram tentativas de atender às peculiaridades da sociedade brasileira, buscando a adequação aos interesses da população. Por outro lado, a partir das novas orientações políticas nascidas do governo militar instaurado em 1964, registrou a história da desmobilização dessas práticas educacionais populares e a adoção da ideologia do capital humano como princípio orientador das iniciativas na área educacional.

Na década anterior, havia sido buscada a modernização do sistema de ensino como estratégia para responder às exigências do modelo desenvolvimentista, salvaguardando-se, contudo, a ordem social vigente. Acentuara-se a ênfase na ideologia nacionalista e no processo de conscientização dos brasilei-

R. bras. Est. pedag. Brasília, 72(1711:145-174, maio/ago. 1991 
ros em relação à sua própria cultura. Foram anos considerados os mais significativos na perspectiva do desenvolvimento econômico, sendo este apoiado na substituição das importações pela presença da produção estrangeira em solo brasileiro. Esse modelo contou com a adesão da burguesia industrial, da burguesia agrária, das forças nacionalistas e dos operários sindicalizados, mas entrou em crise no inicio do governo Jânio Quadros, crise resultante, entre outras causas, de: concentração dos lucros em mãos de grupos nacionais e internacionais; expansão industrial sem concretizar a industrialização e o desenvolvimento nacional; manutenção do arcaísmo da estrutura agrária e privilegiamento do capital estrangeiro. $\mathrm{O}$ modelo dera frutos que consolidaram o poder nas mãos de seus tradicionais detentores e não representara o desejado avanço no sentido do desenvolvimento social.

Ao assumir a presidência, João Goulart adotou uma ideologia vinculada às massas, numa orientação essencialmente populista, buscando uma aliança entre o operariado e a burguesia, voltada para a transformação social. Apesar dos problemas gerados pelo comprometimento de Goulart com o capital estrangeiro e com a ampliação da participação dos trabalhadores nas políticas públicas, linhas de ação aparentemente não conciliáveis, houve nesse período o engajamento de diferentes setores da sociedade brasileira na luta por reformas estruturais, fundamentada numa ideologia desenvolvimentista voltada para a nacionalização do capital. Caracterizou-se o desenvolvimento de uma consciência nacional-popular, que incluía a educação para o povo como uma das estratégias para a transformação pretendida.

O período apresentou-se como de intensa discussão dos princípios educacionais e registrou a participação de muitos brasileiros na luta por reformas sociais via educação de analfabetos. Surgiram diferentes iniciativas inspiradas numa filosofia da educação com base dialética, promovendo um vínculo orgânico entre os intelectuais da educação e as classes desfavorecidas. Ao mesmo tempo, atenuou-se a busca da identificação da cultura popular, através do estudo de suas expressões e manifestações, de suas raízes e de sua história.

Esses movimentos foram interpretados por alguns segmentos da sociedade como desestabilizadores da oruem social vigente e se tornaram alvo de forte repúdio por parte dos setores mais conservadores. Por esse motivo, podem ser incluídos entre os fatores provocadores da ação político-militar em 1964.

Depois de uma fase inicial de ajustamento, em decorrência do Movimento Militar, e do "retorno à ordem", o poder se deslocou das mãos dos políticos para os militares e os tecnocratas. Instalou-se, então, a ideologia da "segurança e desenvolvimento", difundida pela Escola Superior de Guerra, com base numa legislação repressiva para garantir a ordem pública. A educação passou a ser orientada, como foi dito anteriormente, pela teoria do capital humano e, uma vez mais, foi dada ênfase à mobilidade social via escolarização.

O papel da educação era entendido no âmbito da realidade socioeconômica do país e a ela condicionado; assim, o crescimento econômico, o desen- 
volvimento social e a integração do Brasil com a economia mundial, meta pretendida e declarada nos planos nacionais de desenvolvimento, foram apresentados numa relação de dependência com a valorização e a formação do homem brasileiro e a conseqüente política educacional voltada para esses objetivos. A educação tornaria cada homem efetivamente capaz de participar da tarefa de sua auto-realização, da construção nacional e da convivência internacional.

Houve um necessário crescimento da rede escolar e expressivo aumento da matrícula no $1^{2}$ e no 2 - graus para que a educação pudesse exercer o seu papel. A partir de 1968, com subvenção do Estado, ampliou-se o ensino superior privado, mas desde 1965 iniciara-se a implantação e expansão de programas sistemáticos de pós-graduação e a abertura de espaço maior para a pesquisa nas universidades.

Não se pretendeu, nos limites deste trabalho, fazer uma revisão da história do Brasil no período de 1960 a 1971; entretanto, com base na orientação já adotada para a abordagem das exposições de motivos, houve a intenção de buscar a contextualização como perspectiva de análise, uma vez que a educação não existe à margem da sociedade. No contexto político delineado e no referido período, a educação se apresentava como investimento, caracterizando um forte vínculo com a sociedade no plano de sua contribuição ao desenvolvimento econômico; integrava-se aos planos de governo dentro dos mesmos critérios das atividades econômicas e produtivas.

A reforma do ensino superior, realizada em 1968, ocorreu num momento de grande turbulência no mundo acadêmico, que no Brasil se agravara com o novo regime político, sobretudo como conseqüência das práticas repressivas adotadas, bloqueadoras dos canais naturais da manifestação de oposição a esse regime e de crítica à sociedade ${ }^{11}$. Por outro lado, o sistema educacional encontrava-se num processo de mudança de uma orientação acentuadamente humanística para uma orientação pragmática e tecnicista, em face de sua correlação com o desenvolvimento; atendia, pois, a um paradigma economicista.

\subsection{Relatório Geral do Grupo de Trabalho para a Reforma Universitária}

Segundo o texto introdutório do relatório do Grupo de Trabalho, a reforma universitána visaria à eficiência, modernização, flexibilidade administrativa e

\footnotetext{
$\mathrm{Na}$ década de 60, acentuou-se o fenômeno de crescente politização nos estabelecimentos de ensino. As universidades passaram a abrigar movimentos de crítica à sociedade, ao status quo e o papel da própria universidade. Esses movimentos tinham nítida motivação política e podiase reconhecer, em âmbito mundial, a influência das idéias de Mao Tsé-Tung. Muitas são as análises desenvolvidas sobre esse período em especial e, no escopo deste estudo, a referência ao problema tem o limite de introdução ao estudo do relatório do Grupo de Trabalho. Dentro desse limite deve ser considerada.
} 
formação de recursos humanos de alto nível para o desenvolvimento do país, cabendo-lhe, portanto, propor "um repertório de soluções realistas e de medidas operacionais que permitam racionalizar a organização das atividades universitárias, conferindo-Ihes maior eficiência e produtividade" (p.122).

Admitindo que seria papel da própria universidade possibilitar a realização da reforma, os componentes do GT entendiam que ela se efetivaria "numa linha de conciliação difícil, mas necessária, entre o ensino de massa, de objetivos práticos e imediatos, e a missão permanente da universidade, a de constituir-se o centro criador de Ciência e a expressão mais alta da cultura de um povo" (p.122). A reforma foi vista na dinâmica de uma relação dialética entre: o Estado e a universidade, numa relação vertical; a universidade e a comunidade, numa relação horizontal, e entre o mestre e o aluno, no interior da universidade. Essa reciprocidade de relações deveria fazer da universidade "o lugar da confrontação e, ao mesmo tempo da conciliação, também dialética, dos conflitos de gerações, da cultura que nela se produz com a sociedade global; é não somente o lugar privilegiado da transmissão de uma herança cultural mas o instrumento de renovação e mudança" (p.123).

O Estado Intervencionista se impunha como ação disciplinadora e estimuladora, uma vez que a universidade era vista como integrada ao sistema de forças do qual o Estado deveria ser o fator de equilíbrio e direção. $O$ ensino superior era entendido como "investimento prioritário pela sua alta rentabilidade econômica, a longo prazo, e valorização dos recursos humanos", mas a formação do indivíduo deveria sobrepor-se à toda concepção voltada para a formação profissional - a visão humanística preponderando sobre a visão economicista.

A visão humanística permeia a argumentação desenvolvida no documento e se explicita com mais clareza, a nosso ver, nas seguintes assertivas: "em última instância, o grande problema é sempre o homem que utiliza e humaniza o objeto pelo trabalho de seu espírito e de suas mãos" (p.134) e "o problema da reforma universitária em função do aluno porque o aluno é o destinatário imediato de todo esforço educacional de uma nação consciente de que, no jovem, repousam todas as suas esperanças de continuidade na realização de seu próprio destino" (p.140). Mas esse humanismo convive com o papel atribuído à universidade de atuar como instrumento de crescimento econômico.

Se a formação do cidadão é papel da escola (1- e $2^{\circ}$ graus), caberia à universidade, segundo o GT, exercer funções múltiplas de criação de conhecimento e de profissionalização, de desenvolvimento de pesquisa fundamental e de pesquisa aplicada. A implantação de programas sistemáticos de pós-graduação tornara-se urgente para atender à formação de cientistas, professores e "tecnólogos de alto padrão, tendo em vista que a expansão da indústria brasileira requer número crescente de profissionais criadores, capazes de inventar novas técnicas e processos de produção" (p.137).

Ao longo do texto do relatório, a proposta da reforma se delineou procurando integrar o humanismo com o tecnicismo, no esforço de atender à neces- 
sidade de ajustamento da universidade ao modelo tecno-burocrático que regia os diferentes setores da organização político-administrativa do Estado.

$\hat{E}$ preciso entender que esse modelo, embora tendo como suposto fundamental explicitado a realização dos valores humanos via educação, situa a quantidade e a qualidade dos serviços educacionais como dependentes das exigências de recursos humanos para os diferentes setores da economia e submete a demanda social da educação aos critérios do poder do grupo dominante que define o acesso educacional para cada grupo social (Rama, 1984, p.66).

Ao atribuir à universidade a característica de centro de investigação científica e tecnológica voltado para a autonomia da expansão industrial brasileira, produtor, portanto, de tecnologia indispensável ao desenvolvimento econômico, o GT enfatizou o atendimento aos setores da economia; entretanto, reiteradas vezes foi assinalada a necessidade de serem levadas em conta as legítimas aspirações culturais do jovem e a contribuição da universidade para o desenvolvimento integral do educando. As tensões existentes entre essas duas orientações são consideradas inevitáveis e difíceis de conciliar pelo GT, bem como as decorrentes entre a democratização do acesso ao ensino superior e a dimensão essencial da "manutenção da alta cultura que permanece o privilégio de alguns".

Considerado o modelo tecno-burocratico que permanece subjacente ao relatório em estudo e que permite identificar o papel ativo da educação na formação de técnicos capazes de viabilizar esse modelo sem análises valorativas, a assertiva "as proposições normativas que fluem da ética se conciliam plenamente com as proposições indicativas que decorrem da realidade econômica" (p.142) perde sua consistência enquanto conteúdo de conciliação entre o humanismo e a tecnocracia e se apresenta como reforço aos conteúdos ideológicos do referido modelo.

\subsection{Relatório do Grupo de Trabalho - Reforma de Ensino de $1^{9}$ e de $2^{\circ}$ Graus}

A política educacional apoiada no cientificismo tecnocrático, que orientou a proposta da reforma do ensino superior, foi, também, inspiradora da reforma do ensino de $1^{\mathrm{e}}$ e de $2^{\circ}$ graus. O ideal pragmático e utilitarista permeou a exposição dos componentes do GT e o conceito de educação integral foi definido abrigando a educação para o trabalho. Para que se entenda melhor como esse ideal pode ser percebido nos diferentes argumentos que explicitam uma orientação mais humanística, voltada para as aspirações e necessidades da criança e do jovem brasileiros, alguns pontos do relatório em estudo precisam ser destacados.

O primeiro deles se refere a como os membros do GT entenderam o que seria a reforma. Ela foi vista não como uma mera substituição de plano, mas como um atributo da própria organização para dar à escola a capacidade de se atualizar pela exploração mais ampla de suas próprias virtualidades, embora 
naquele momento fosse a via legislativa o caminho para lançar as bases do que seria um estilo a se impor gradualmente: a atualização refletindo a dinâmica do processo de escolarização (p.2). Permaneceu, pois, o sentido de atualização e expansão, já acolhido pela exposição de motivos de Clemente Mariani ao considerar o seu projeto como uma "constituição do ensino" e atribuir às instituições de ensino, organismos vivos e progressivos, a revisão de suas orientações em resposta à própria dinâmica. A expansão se caracterizou como categoria quantitativa e a atualização como categoria qualitativa, ambas se configurando como categorias interatuantes de um processo de equalização do sistema de ensino, que se inseria na proposta de democratização desse sistema.

A democratização do sistema de ensino se abriga no conceito de democracia e no exercício dos direitos civis, políticos e sociais dos cidadãos, assegurados nos princípios básicos da tese da democracia. Embora o Estado Autoritário, forma de organização política então vigente, tivesse como características, entre outras, a tutelação do exercício político das diferentes camadas sociais e a submissão da sociedade às regras por ele gerenciadas, era com base na democracia que a Constituição em vigor assegurava ao indivíduo o direito à educação, sendo dever do Estado promovê-la em seus diferentes níveis e graus e garantir a oferta do ensino a todas as crianças e pré-adolescentes de 7 a Manos

A tese da democratização do ensino inspirou, portanto, a proposta da reforma, na qual alguns aspectos expressaram mais claramente essa tese. Foram eles, a nosso ver. 1) a estrutura, com base no princípio da integração; 2) o currículo, fundamentado na conciliação entre o ensino acadêmico e o ensino profissionalizante, defendendo a escola única; 3) a organização e o funcionamento, tendo como suporte o princípio da autonomia; 4) o financiamento, defendendo maior assistência financeira aos sistemas que tivessem menos recursos disponíveis.

A integração vertical foi apresentada no sentido de remover todas as barreiras de ordem administrativa e pedagógica que caracterizavam a estrutura anterior de um sistema de divisão quádrupla. Essas limitações externas, segundo o GT, explicavam-se tão-somente por motivos socioeconômicos: "Refletindo inicialmente a estratificação social, ela tende numa segunda fase a indicar apenas o grau de escolarização que uma sociedade pode oferecer a todos os segmentos progressivamente mais reduzidos de sua população" (p.4). Por dispositivo constitucional, a escolarização dos 7 aos 14 anos já se tornara obrigatória, integrando, portanto, dois segmentos (primário e ginásio) e preestabecendo, conseqüentemente, a forma tríplice da estrutura do sistema de ensino; essa medida buscava assegurar um nível elevado de escolarização a todos os brasileiros, aos quais as novas técnicas de produção e o maior desenvolvimento socioeconômico estavam a exigir a educação como necessidade imediata.

A integração horizontal complementou a integração vertical numa perspectiva de organicidaae, no sentido de uma proposta inovadora que, abran- 
gendo tanto o segundo segmento do $1^{\circ}$ grau quanto o $2^{\circ}$ grau, buscou fazer desaparecer a característica de dualidade que permanecera no ensino secundário nos diferentes ramos de ensino - comercial, industrial, agrícola e normal, apesar dos avanços conquistados na Lei 4.024 em relação à articulação desses ramos com o ginasial e com o $2^{\circ}$ ciclo do curso secundário. Essa integração teve sua maior expressão no $2^{\circ}$ - grau, cuja identidade passou a ser a de "um ensino sobre uma base de estudos gerais e comuns que se abra num leque de tantas habilitações, dentre as suscetíveis de desenvolvimento a esse nível, quantas sejam as reclamadas pelo mercado de trabalho" (p.10); o ensino acadêmico e o ensino técnico estariam conciliados num $2^{\circ}$ grau que se concluiria sempre por uma formação profissional.

A escola única foi, portanto, concretizada no princípio de integração e se operacionalizou no currículo proposto, cujos conteúdos de educação geral e formação especial atenderiam, respectivamente, à transmissão de um acervo comum de idéias fundamentais, buscando situar o aluno na sociedade e na cultura de seu tempo, e à iniciação ao trabalho e à formação profissional ou ao aprofundamento em determinada ordem de estudos gerais, este exclusivamente no ensino de 2- grau e fugindo à regra de profissionalização (p.13-14).

Considerando que a organização administrativa, didática e disciplinar seria da competência de cada estabelecimento de ensino, uma vez que estaria regulada em seu respectivo regimento, os membros do GT restringiram-se, no que se refqria às normas de organização e funcionamento, ao que consideraram como diretrizes e bases estritamente indispensáveis em âmbito nacional. Deste modo, o regimento objetivaria a lei no nível de cada instituição de ensino, resguardando sua nítida individualidade.

Por certo, a descentralização é corolário da autonomia; assim, houve uma necessária atribuição de competências normativas e administrativas para que pudesse caracterizar-se a autonomia pedagógica. Em conseqüência, o relatório preocupou-se com os objetivos e a amplitude das matérias relativas ao núcleo comum, obrigatório em nível nacional, deixando o seu desenvolvimento e conteúdos como elementos do plano do estabelecimento de ensino. É preciso registrar que a parte diversificada - toda e qualquer matéria não incluída no núcleo comum e que a ele se acrescentaria para compor o currículo pleno - seria definida totalmente no nível do sistema estadual e/ou da própria escola.

O financiamento é o quarto aspecto que se desejou abordar. Entre os muitos dispositivos que representaram medidas que deveriam promover melhor assistência financeira e maior distribuição de recursos, com fundamento em dispositivos constitucionais, a concessão de auxílio da União, inversamente proporcional ao índice de renda per capita na jurisdição do sisterna a ser beneficiado e diretamente proporcional à população a ser escolarizada na área geográfica, apresentou-se como o mecanismo mais forte ao favorecimento da democratização do ensino.

Essa democratização se consubstanciou, ao longo do relatório, com uma dupla face: atender às aspirações individuais e responder a necessidades sociais resultantes do modelo econômico de desenvolvimento. Não se percebe 
um ideal educativo, nem uma teoria pedagógica foi explicitada, embora a argumentação se construa em torno da oferta de uma escolarização mais extensa e de melhor qualidade a todos os brasileiros - crianças, jovens e adultos -, estes situados numa proposta inovadora de ensino supletivo. Há, entretanto, uma concepção que permaneceu subjacente: a de um país em pleno desenvolvimento que precisaria superar as forças impeditivas de seu progresso, entre as quais se encontrava um sistema de ensino inadequado à nova realidade. Apesar dos muitos períodos desveladores dessa concepção, apenas dois serão transcritos: 1) o que se refere à orientação para o planejamento do 2- grau: "partindo de que todos, num país como o Brasil, devem chegar à idade adulta com algum preparo para o trabalho"; 2) o que explica o conceito de "terminalidade real": "para o tipo de aluno dos meios pobres, amadurecido precocemente pelas dificuldades da vida, a iniciação antecipada numa atividade produtiva será mal menor, decerto, que um acréscimo de estudos gerais fuja função se perderá e cuja utilidade ele não poderá perceber" (p.9). No entanto, a característica mais acentuada da referida concepção é a habilitação profissional obrigatória no nivel do $2^{\circ}$ grau, que não tem nenhum outro fundamento ao longo do relatório a não ser o econômico, o de preparação de recursos humanos para atender à demanda de mão-de-obra qualificada.

\section{Algumas considerações finais}

As exposições de motivos e os relatórios de grupos de trabalho, por precederem e introduzirem a legislação de ensino, foram selecionados como documentos de análise para uma possível identificação dos valores subjacentes, inspiradores da política educacional.

A questão mais ampla deste estudo se situa na relação entre filosofia da educação e política educacional, e a filosofia é entendida como pré-condição para o estabelecimento dessa política. Por esse motivo, o ponto de partida foi o papel da filosofia da educação, o que exigiu o exame dos conceitos de cultura e de ideologia para a reflexão sobre a relação essencial entre valores e educação.

Ao longo do trabalho desenvolvido, foram procurados os valores subjacentes ao discurso argumentativo construído para explicar e defender as orientações adotadas. No período que abrange as Reformas de 31,42 e 61, o paradigma teórico da educação se configurou numa perspectiva humanística, voltada para a contribuição da ação educativa formal e sistemática, ou seja, da escolarização, à vigência de uma ordem política democrática e à consolidação do Estado Nacional. Historicamente, entretanto, desde a década de 50, o sistema político-institucional já abrigava uma teoria educacional fundamentada no vínculo entre educação e sociedade, no plano da contribuição educacional ao desenvolvimento econômico. No entanto, esse paradigma economicista, apoiado nos conceitos e quadros teóricos da análise sociológica funcionalista, só veio a se impor nos textos dos grupos de trabalho das Reformas de 68 e 71. 
A conceituação de política educacional faz-se, agora, necessária para estabelecer, na estrutura deste estudo, sua relação com a filosofia da educação. Assim, explicita-se que o conceito adotado foi: conjunto de diretrizes e ações inspiradas por uma filosofia do dever fazer, voltado para o atingimento dos objetivos da educação; sendo considerada, pois, em seu duplo sentido de diretriz e de ação prática.

Admitindo-se que a filosofia da educação seja pré-condição para o estabelecimento dessa politica e que os valores se expressam nessa filosofia, a politica educacional se configura como um corpo de idéias e valores coerentes entre si, em função do que deve ser realizado. Percebe-se, pois, que os objetivos da educação são definidos a priori, no momento em que o governo escoIhe os valores que irá privilegiar e os hierarquiza.

Esses objetivos representam, portanto, a filosofia orientadora da ação governamental; logo, pode-se tomar como pressuposto que a política educacional representa (ou deve representar) uma filosofia de educação.

No nível do discurso, há um modelo educacional de concepção idealista, que se apresenta coerente e lógico, mas que não leva em conta os dados da realidade. No nível da estrutura organizacional e no dinamismo operacional do funcionamento do sistema de ensino, ocorre a prática educacional, num conjunto de contradições emergentes aa situação real concreta; esse conjunto decorre dos interesse manifestos e das forças antagônicas em ação numa sociedade de classes em condições acentuadamente desiguais. Portanto, é no nível da estrutura organizacional que se expressa nas normas, nas diretrizes e nos planos, que a prática educacional se "ideologiza", isto é, a racionalização presente no discurso e a maior intensidade de determinadas forças conduzem à hegemonia de interesses circunscritos a alguns grupos, o que distorce a proposta política. Por esta razão, pode-se afirmar que têm sido colocados em prática interesses e intenções do governo e de grupos dominantes, sem atender às aspirações legítimas da sociedade brasileira.

Se a filosofia fundamenta a política, esta não deveria contrariai sua raiz: pressupõe-se uma integração harmônica entre a politica do governo e a da educação. No entanto, a filosofia educacional no Brasil é que parece fundamentar-se num compromisso político não revelado e, em conseqüência, a política educacional não expressa o sentido axiológico que a inspira. Suas estratégias sequer têm favorecido o atendimento ao compromisso com a posição filosófica identificada nos documentos analisados neste estudo; na prática que se desenvolve no nível de administração do sistema de ensino, os valores conceitucicos e hierarquizados são substituídos por valores distanciados da posição filosófica assumida e até por valores antagônicos ao dever fazer explicitado pela política ecucacional declarada.

Assim, questiona-se, na relação entre filosofia da educação e política educacional, a convivência entre os valores idealizados, os valores reais, subjacentes à operacionalização das diretrizes políticas, e os valores que representam os anseios da população.

R. bras. Est. pedag. Brasília, 72(1711:145-174, maio/ago. 1991 
É nesta circunstância que se retoma a necessária reflexão sobre filosofia da educação e política educacional, a partir de posições definidas por Saviani e Trigueiro Mendes, e se constata a limitação deste estudo no atingimento de seu objetivo mais amplo:

"... nós estamos hoje, no âmbito da política educacional e no âmbito do interior da escola, na verdade nos digladiando com duas posições antitéticas e que, via de regra, convencionalmente são traduzidas em termos do novo e do velho, da pedagogia nova e da pedagogia tradicional" (Saviani, 1985, p.42).

"A educação aparece sem filosofia, sem política, sem economia, desligada ao mesmo tempo de seus objetivos e valores reais, como de suas condições históricas e sócio-culturais. Sobram apenas algumas instrumentalidades, que não vão servir à educação, esvaziada, mas ao Poder, que passa a ocupar o vazio determinado pela ausência de todas as categorias que deveriam estruturar o pensamento e a política educacionais" (Trigueiro Mendes, 1987, p.89).

\section{Referências bibliográficas}

ABREU, Jayme. A escola agente de mudança cultural. In: BRASIL. Ministério da Educação e Cultura. Educação no Brasil. Brasília, 1976. p.28-51.

COMPARATO, Fábio Konder. Educação, estado e poder. São Paulo: Brasiliense, 1987.

COSTA, Lena C. B. Ferreira. A educação no Brasil. In: SOUZA, Paulo Nathanael Pereira de, SILVA, Eurides Brito (Coords.) Educação: escola e trabalho. São Paulo: Brasiliense, 1987.p. 109-64.

FREIRE, Paulo. Educação como prática da liberdade. Rio de Janeiro: Paz e Terra, 1974.

GEERTZ, Glifford. A interpretação das culturas. Rio de Janeiro: Zahar, [19- -].

GRANATO, Teresinha A. C. Notas de aula: curso de doutorado em educação brasileira. Rio de Janeiro: UFRJ, 1988.

HESSEN, Johannes. Filosofia dos valores. Tradução por L. Cabral de Moncada. 5. ed. Coimbra: Armênio Amado Edit. Sucessor, 1980.

HORTA, José Silvério Baía. Planejamento educacional. In: MENDES, Durmeval Trigueiro (Coord.) Filosofia da educação brasileira 3. ed. Rio de Janeiro: Civilização Brasileira, 1987. p. 195-239.

MAIA, Nelly Aleotti. Notas de aula: curso de doutorado em educação brasileira. Rio de Janeiro: UFRJ, 1987.

MATTEO, Vincenzo Di. Valores sociais e educação: uma reflexão filosófica. Symposium, Recife, v.25, n.l, 1983.

MENDES, Durmeval Trigueiro. Existe uma filosofia da educação brasileira? In:

------ . (Coord.). Filosofia da educação brasileira. 3. ed. Rio de Janeiro: Civilização Brasileira, 1987.

NOGUEIRA, S. M. A. Valor e educação: uma reflexão sobre o cotidiano do ideal pedagógico. Rio de Janeiro: UFRJ, $1987.21 \mathrm{p}$.

RAMA, German. Estilos educacionais, in: DESENVOLVIMENTO e educação na América Latina. Tradução por Maura Iglêsias. 2. ed. São Paulo: Cortez, Autores Associados, 1984. p.46-83. 
RIBEIRO, Méria Luisa S. História da educação brasileira: a organização escolar. São Paulo: Moraes, 1981.

ROMANELLI. Otaíza O. História da educação no Brasil. Petrópolis: Vozes, 1986.

SAVIANI, D. Escola e democracia. São Paulo: Cortez, Autores Associados, 1985. Tendências e correntes da educação no Brasil. In: MENDES, Durmeval Tri gueiro (Coord.). Filosofia da educação brasileira. 3 ed. Rio de Janeiro: Civilização Brasileira, 1987. p.19-47

SCHWARTZMAN, Simon et al. Tempos de Capanema. Rio de Janeiro: Paz e Terra; São Paulo: USP, 1984.

SUCHOCOLSKI, B. La pédagogie et les grandes courants philosophiques. Paris: Les Editions du Seara bée, 1960.

VILALOBOS, João E. O problema dos valores na formação e no funcionamento do sistema educacional brasileiro. Revista Brasileira de Estudos Pedagógicos, Rio de Janeiro, v.33, n.76, p.34-49, out./dez. 1959.

Documentos

EXPOSIÇÃO de Motivos da Reforma de Ensino Secundário. In: EDUCAÇÃO e

Cultura. Rio de Janeiro. Olympio, 1940. EXPOSIÇÃO de Motivos da Lei Orgânica do Ensino Secundário. EXPOSIÇÃO de Motivos do Ministro da Educação e Saúde.

Diário Oficial, Brasília,

27 fef. 1942. Lei Orgânica do Ensino Industrial. EXPOSIÇÃO de Motivos do Ministro da Educação e Saúde. Diário Oficial, Brasília

20 dez. 1943. Lei Orgânica do Ensino Comercial. EXPOSIÇÃO de Motivos do Ministro da Educação e Saúde Lei Orgânica do Ensino Primário, fotocópia. EXPOSIÇÃO de Motivos. Revista Brasileira de Estudos Pedagógicos, Rio de Janeiro, v.13, p.5-22, ago. 1949. RELATÓRIO Geral do Grupo de Trabalho para a Reforma Universitária. Revista

Brasileira de Estudos Pedagógicos, Rio de Janeiro, v.50, n.111, p.122-58, jul./set. 1968.

RELATÓRIO Grupo de Trabalho. Brasília: MEC, 1970. mimeo.

Recebido em 14 de agosto de 1991

Sônia Martins de Almeida Nogueira é mestre em Educação e professora-adjunta da Faculdade de Educação da Universidade Federal do Rio de Janeiro (UFRJ). 
This study is intended to go into two questions that are brought up on a basis of the analysis of the relationship between school, Society and Culture. These questions have to do with the role of philosophy of education and the intervention of Government through legislation on education. A brief commentary is thus developed on the philosophy of education, taking into account the close relationship between education and axiology, and an analysis is made of the explanatory introduetions and work groups' reports, drawn up for Présentation and justification of documents on the reforms of 1931, 1942, 1964, 1968 and 1971. The argumentation is built up in questfor those factores favouring identification of subjacent values that might bring to light the actual political intention of breaking up the educational system with its objectives and values pur suant to educational philosophy.

Cette étude veut analyser deux questions qui se posem à partir du rapport école/société!Culture. Ces questions se réfèrent au role de là philosophie de l'éducation et à Vintervention de 1'Etat dans l'éducation, au moyen de là legislation portant sur 1'enseignement. On développe, portant, une breve reflexión sur là philosophie de $V$ éducation, compte tenu d'un intime rapport entre éducation et axiologie, et Von analyse les exposés de motifs et les rapports de groupes de travail, elabores aux fins de Présentation et justification des documents des reformes de 1'enseignement de 1931, 1942, 1964, 1968 et 1971 à là recherche d'éléments qui favorisent l'identification de valeurs sous-jacentes, qui pourraient révéler une réelle intention politique de rupture entre le système d'enseignemtnt et les objectifs et les valeurs de là philosophie éducationnelle.

Este estúdio pretende explorar dos Cuestiones que se plantean a partir del análisis de là relación escuela/sociedad/cultura. Dichas questiones se refieren al papel de Ia filosofia de Ia educación, y a Ia intervención del Estado en là educación a través de là legisloción educativa. Así, se desarrollo una breve reflexión sobre Ia filosofia de là educación, considerada una íntima relación entre educación y axiología, y se analizan Ias expresiones set re motivos, e informes de grifos de trabajo, elaborados para là presentación y como justificativa de los documentos de Ias reformas de là ensenanza de 1931, 1942, 1964, 1968 y 1971, buscándose elementos que favorezean là identificación de valores svlyacentes, posibles reveladores de una efectiva intención política de ruptura del sistema de ensenanza con respecto a los objetivos y valores de là filosofia educacional. 